\title{
Molecular evolution of the crustacean hyperglycemic hormone family in ecdysozoans
}

\author{
Nicolas Montagné ${ }^{1}$, Yves Desdevises ${ }^{2}$, Daniel Soyez ${ }^{3}$, Jean-Yves Toullec ${ }^{4^{*}}$
}

\begin{abstract}
Background: Crustacean Hyperglycemic Hormone $(\mathrm{CHH})$ family peptides are neurohormones known to regulate several important functions in decapod crustaceans such as ionic and energetic metabolism, molting and reproduction. The structural conservation of these peptides, together with the variety of functions they display, led us to investigate their evolutionary history. CHH family peptides exist in insects (Ion Transport Peptides) and may be present in all ecdysozoans as well. In order to extend the evolutionary study to the entire family, $\mathrm{CHH}$ family peptides were thus searched in taxa outside decapods, where they have been, to date, poorly investigated.

Results: CHH family peptides were characterized by molecular cloning in a branchiopod crustacean, Daphnia magna, and in a collembolan, Folsomia candida. Genes encoding such peptides were also rebuilt in silico from genomic sequences of another branchiopod, a chelicerate and two nematodes. These sequences were included in updated datasets to build phylogenies of the $\mathrm{CHH}$ family in pancrustaceans. These phylogenies suggest that peptides found in Branchiopoda and Collembola are more closely related to insect ITPs than to crustacean CHHs. Datasets were also used to support a phylogenetic hypothesis about pancrustacean relationships, which, in addition to gene structures, allowed us to propose two evolutionary scenarios of this multigenic family in ecdysozoans.

Conclusions: Evolutionary scenarios suggest that $\mathrm{CHH}$ family genes of ecdysozoans originate from an ancestral two-exon gene, and genes of arthropods from a three-exon one. In malacostracans, the evolution of the $\mathrm{CHH}$ family has involved several duplication, insertion or deletion events, leading to neuropeptides with a wide variety of functions, as observed in decapods. This family could thus constitute a promising model to investigate the links between gene duplications and functional divergence.
\end{abstract}

\section{Background}

The study of the evolutionary history of arthropods is a challenging field of research, as they constitute the large majority of known metazoan species and exhibit an extreme diversity of body plans and physiology. Nowadays, evo-devo approaches largely contribute to this research area [reviewed in [1]], but the evolution of peptide hormone families directly involved in physiological adaptations remains poorly investigated in arthropods, especially when compared to vertebrates. The Crustacean Hyperglycemic Hormone ( $\mathrm{CHH}$ ) family could constitute a model of choice to address this question, as $\mathrm{CHH}$ family peptides are well known in decapod crustaceans, where they do play major roles in many

\footnotetext{
* Correspondence: jean-yves.toullec@sb-roscoff.fr

${ }^{4}$ UPMC Univ Paris 06, UMR 7144 CNRS - Adaptation et Diversité en Milieu Marin, Station Biologique de Roscoff, F-29682, Roscoff, France
}

physiological processes. Since decapods were the first invertebrates where a neuroendocrine mechanism was discovered, they have been extensively used in comparative endocrinology studies, and $\mathrm{CHH}$ has become the archetype of a neuropeptide family including around 150 members to date [reviewed in [2-4]]. CHH family peptides are 72 to 78 amino acids long and are, based on structural features, divided into two sub-families [5]. Type I peptides, the CHHs sensu stricto, are pleiotropic hormones involved in the regulation of energetic and ionic metabolism and, in addition, can also exert an inhibitory effect on molting and reproduction [reviewed in [6]]. By a tissue-specific alternative splicing mechanism, $\mathrm{CHH}$ genes produce a second peptide, devoid of hyperglycemic activity, named $\mathrm{CHH}-\mathrm{L}$ (for $\mathrm{CHH}$ long isoform), which may be involved in osmoregulation [7-9]. Type II peptides, namely the molt-inhibiting 
hormones (MIHs), the vitellogenesis-inhibiting hormones (VIHs) and the mandibular organ-inhibiting hormones (MOIHs), are functionally more specialized than CHHs. Characterized through their inhibitory actions on molting and reproduction, they never elicit hyperglycemia [reviewed in $[2,10]]$.

The evolution of CHHs has been recently discussed in decapods [11] and we have intended here to extend the evolutionary study to the entire family, by including data from non-decapod taxa. Little is known about the $\mathrm{CHH}$ family outside decapods, but it may be present in the entire Arthropoda, and even in all Ecdysozoa. Indeed, a $\mathrm{CHH}$ and a VIH were isolated from an isopod crustacean [12,13], and neuropeptides sharing the same structural signature, the ion transport peptides (ITPs), were also characterized in several insect species [reviewed in [14]]. As for decapod CHHs, ITP genes produce an ITP-L isoform by alternative splicing, whose function remains elusive. To go further, heterologous immunostainings revealed the occurrence of $\mathrm{CHH}$-like peptides in two branchiopods [15], a myriapod [16] and a chelicerate [17], and a gene was found in the genome of the nematode Caenorhabditis elegans, which encodes a putative peptide exhibiting a $\mathrm{CHH}$ family structural signature [3]. To increase our knowledge on the $\mathrm{CHH}$ family in the taxa cited above, we have conducted an in silico study on available genomic sequences from arthropods and nematodes. Exon-intron patterns of the genes were determined and sequences of putative $\mathrm{CHH}$ family peptides were deciphered. In addition, $\mathrm{CHH}$ family sequences were obtained by molecular cloning in a collembolan and in a branchiopod, whose phylogenetic positions are currently uncertain. Indeed, the grouping of crustaceans and hexapods in a Pancrustacea clade is widely accepted but the relationships inside Pancrustacea remain controversial. Recent molecular phylogenies based on mitochondrial genes (Figure 1A) notably yield a paraphyletic Hexapoda, with Collembola separated from Insecta, and Branchiopoda as a sister-group to Malacostraca and Cephalocarida [18-20]. These phylogenies largely differ from those based on nuclear genes (Figure 1B), where Hexapoda appears monophyletic, and Branchiopoda are generally sister-group to Hexapods [21-23].

Newly characterized sequences were included in $\mathrm{CHH}$ family sequence datasets, which were then used to build phylogenies of this family and to investigate its evolutionary history. Because of the reduced size of these datasets, a test was conducted to assess which of the two phylogenetic hypotheses presented Figure 1 was more strongly supported by our data, and could be further used as a basis to elaborate evolutionary scenarios of the $\mathrm{CHH}$ family genes.

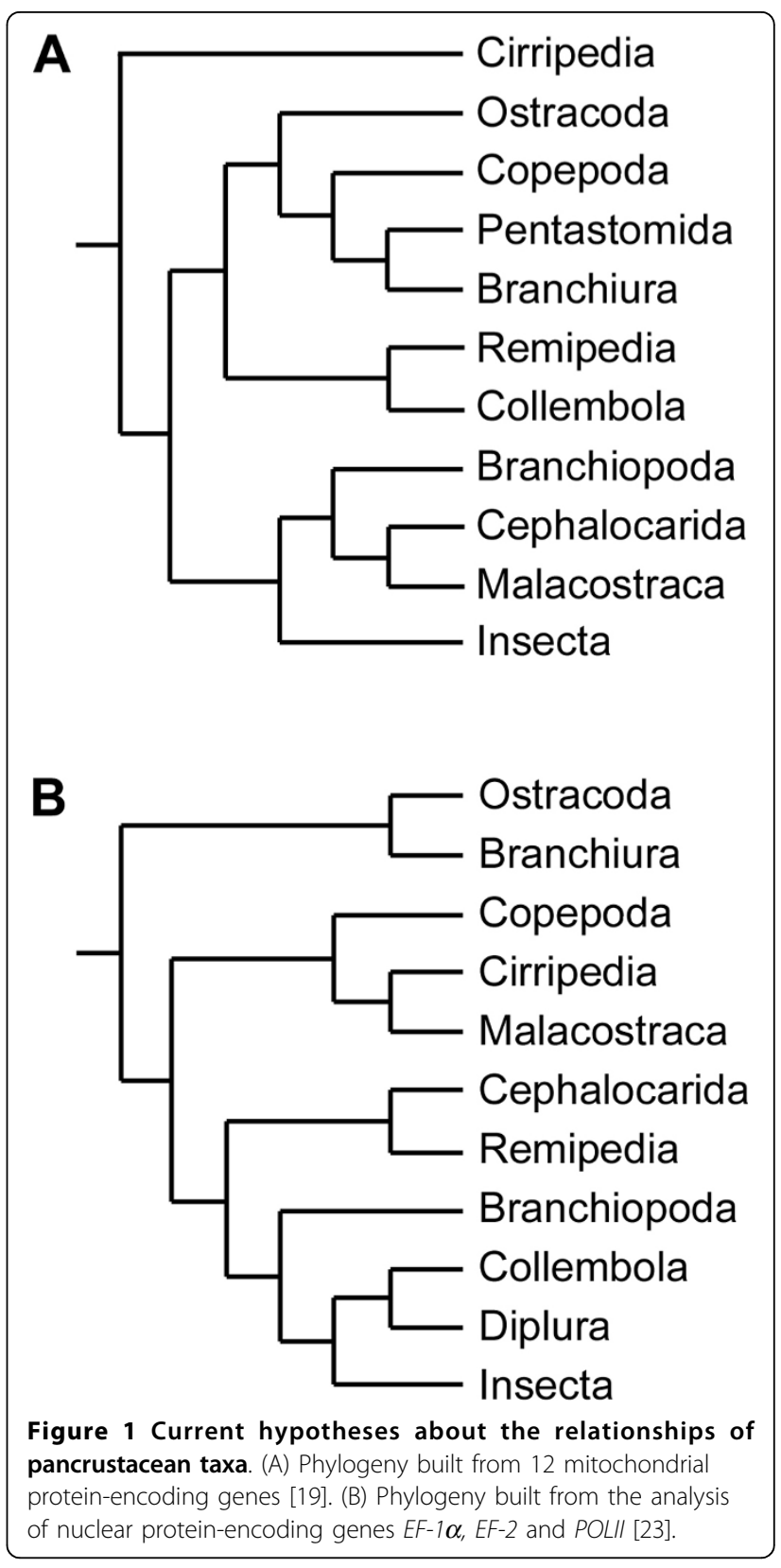

\section{Results}

CHH family peptides characterized in Daphnia magna and Folsomia candida

In the branchiopod Daphnia magna, RT-PCRs conducted with degenerate primers designed from insect ITP transcripts and followed by 3'-5'RACE produced two complete cDNAs. Their length was 1053 and 1198 $\mathrm{bp}$, respectively, and they encoded peptide precursors composed of a signal peptide, a precursor-related peptide and a mature hormone. The two cDNA sequences were identical except for a $145 \mathrm{bp}$ stretch (position 383 to 527) present in only one of them, suggesting the 
occurrence of an alternative splicing during mRNA processing. The short cDNA encoded a 72-residue peptide with a C-terminus end putatively amidated, which was named ion transport peptide (ITP) as it appeared to be related to insect ITPs (Figure 2A). On the other hand, the long cDNA encoded a non-amidated peptide of 79 amino acids, only differing from ITP after the fortieth residue, which was named ITP-L (Figure 2B).

The two complete cDNA sequences obtained from the collembolan Folsomia candida led to similar results: two transcripts of different lengths (1307 and 2018 bp) encoded prepro-peptides which only differed after the fortieth residue of the mature peptide. The 72 residue amidated peptide, translated from the short cDNA, was named ITP and the 82 residue non-amidated peptide, translated from the longest CDNA, was named ITP-L (Figure 2A and 2B).

\section{Sequences characterized in silico}

For the insects Anopheles gambiae, Apis mellifera, Culex pipiens, Nasonia vitripennis and Pediculus humanus, nucleotide sequences encoding for ITP or ITP-L, which have not been recovered by automatic annotation programs were deduced from the gene sequence following alternative splicing rules. A gene encoding putative ITP and ITP-L isoforms was also found in the genome of another water flea, Daphnia pulex. At the present time, both ITP (72 or 73 residue amidated peptides) and ITP-L (79 to 90 residue non-amidated peptides) sequences are available from 12 insect and two branchiopod species (Figure 2A and 2B).

In the genome of the deer tick Ixodes scapularis (Chelicerata), a gene was found that encoded only one mature ITP-like peptide. In addition, cDNA and peptide sequences of another ITP-like peptide were found,

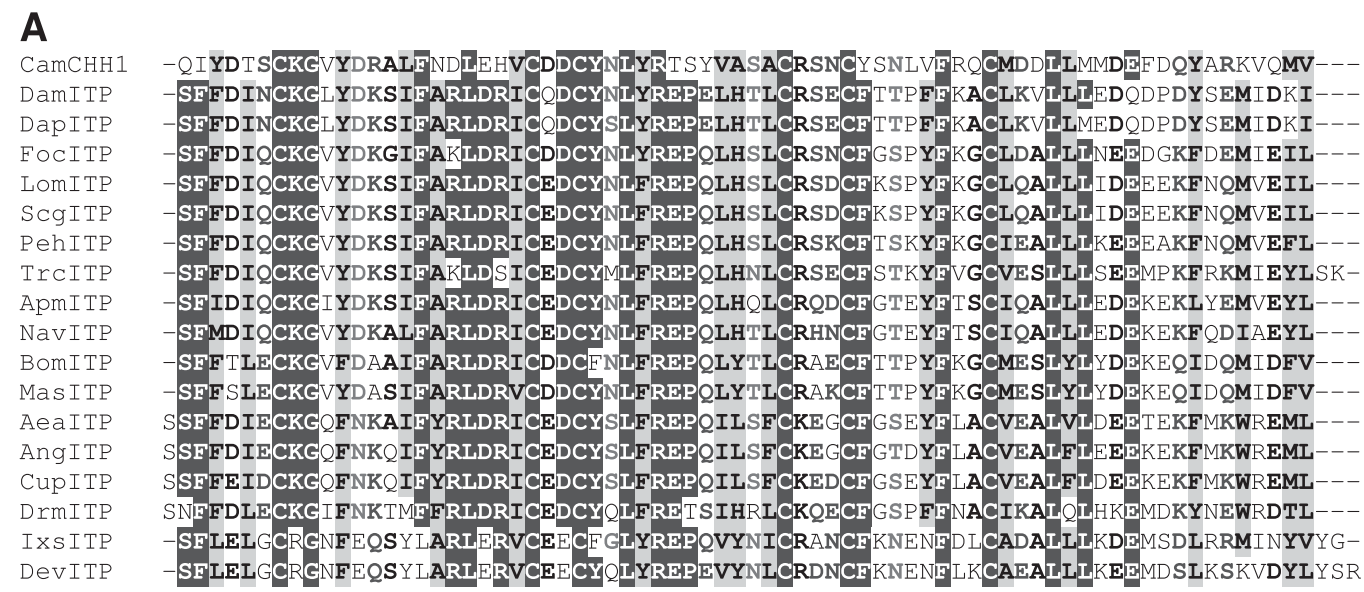

B

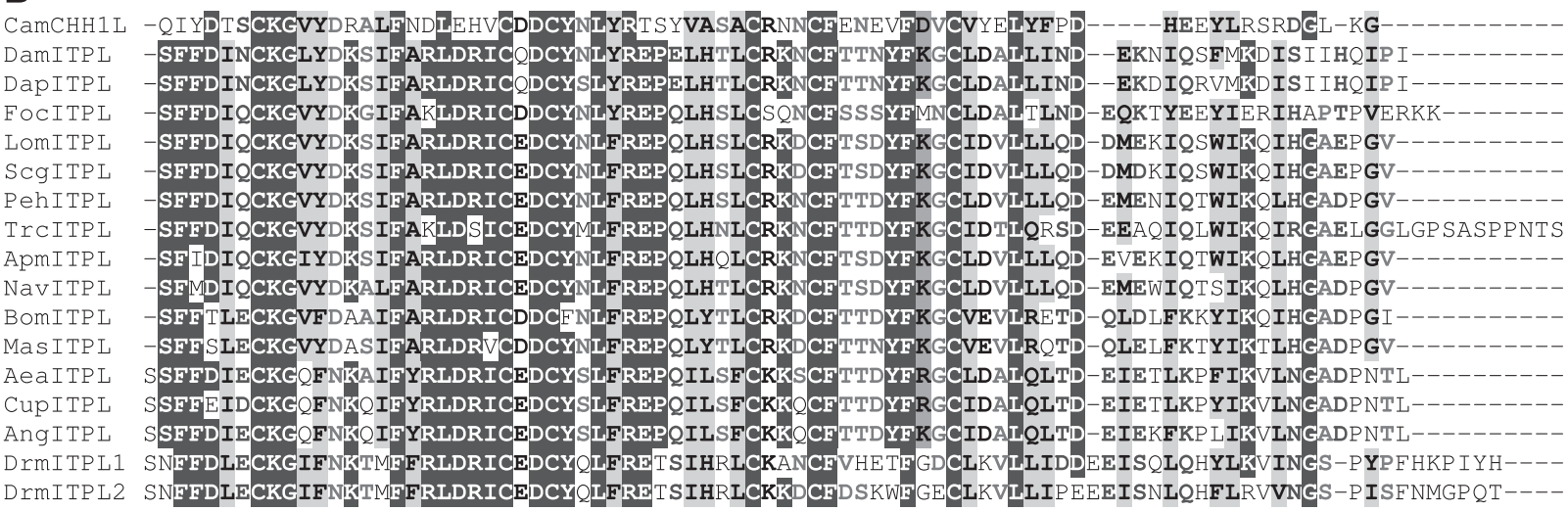

Figure 2 Alignments of the putative ITP (ion transport peptide) and ITP-L sequences from branchiopods, collembolans, insects and chelicerates. (A) Multiple-sequence alignment of 17 ITP sequences with $\mathrm{CHH}$ (crustacean hyperglycemic hormone) sequence from the shore crab Carcinus maenas. (B) Multiple-sequence alignment of 16 ITP-L sequences with CHH-L sequence from Carcinus maenas. Aea: Aedes aegypti ; Ang: Anopheles gambiae; Apm: Apis mellifera ; Bom: Bombyx mori ; Cam: Carcinus maenas ; Cup: Culex pipiens ; Dam: Daphnia magna ; Dap: Daphnia pulex; Dev: Dermacentor variabilis ; Drm: Drosophila melanogaster ; Foc: Folsomia candida ; Ixs: Ixodes scapularis ; Lom: Locusta migratoria ; Mas: Manduca sexta ; Nav: Nasonia vitripennis ; Peh: Pediculus humanus ; Scg: Schistocerca gregaria ; Trc: Tribolium castaneum. Sequence accession numbers are given in Table 2 
during database mining, in the American dog tick Dermacentor variabilis. These peptides are 74 and 75 residue long, respectively, and are not amidated on their C-terminal end (Figure 2A).

In the Caenorhabditis elegans genome, the gene ZC168.2 has been described as putatively encoding a $\mathrm{CHH}$ family peptide of 83 amino acid residues [3]. In the present study, a second gene (CO5E11.6) which may encode another putative $\mathrm{CHH}$ family peptide was found in the $C$. elegans genome: this gene encodes a mature peptide of 97 amino acids containing six cysteyl residues whose positions are similar to those found in $\mathrm{CHH}$ family hormones (Figure 3 ). The corresponding peptides ZC168.2 and C05E11.6 were named ITP 1 and ITP 2, respectively, based on their similarity with insect ITPs and without predicting any physiological function. Similar ITP 1 and ITP 2 peptides were also deduced from the genomes of Caenorhabditis briggsae and Caenorhabditis remanei. Finally, single $\mathrm{CHH}$ family peptides were deduced from the genomes of the Malaysian filarial worm Brugia malayi and the whipworm Trichinella spiralis. These putative peptides were 102 and 60 amino acids long, respectively (Figure 3).

For each of the genes described here, exon-intron structures were determined and compared to those already described (Figure 4). These data were further used, in addition to phylogenetic information, to infer evolutionary scenarios of the $\mathrm{CHH}$ family.

\section{Phylogeny of $\mathrm{CHH}$ family peptides in Pancrustacea}

In the maximum-likelihood (ML) phylogeny of pancrustacean $\mathrm{CHH}$ family peptides (Figure 5), type I and type II peptides of decapods were both arranged in monophyletic sub-groups. Type I and II peptide clades were also found in the phylogeny built by Bayesian inference
(BI) based on the DNA dataset. The "type I" clade, supported by a bootstrap value of $95 \%$ in the ML analysis (posterior probability, or pp, of 1.00 in $\mathrm{BI}$ ), contained all $\mathrm{CHH}$ from decapods, with the $\mathrm{CHH}$ from the isopod Armadillidium vulgare at their base. Similarly, the "type II" clade, supported by a bootstrap value of $100 \%$ (pp of 1.00 in $\mathrm{BI}$ ), contained all MIHs, VIHs and MOIHs from decapods, with the isopod VIH at their base. This topology suggests that the type I and type II peptide genes constitute paralogous lineages, which have appeared by duplication of an ancestral gene before the radiation of malacostracans (taxa that contains decapods and isopods). Inside the type I clade, the clade of Dendrobranchiata (peneid shrimps) CHHs encoded by three-exon genes is at the base of the other decapod CHHs, encoded by four-exon genes, found both in Dendrobranchiata and Pleocyemata (the remaining decapods). It suggests that a duplication of a $\mathrm{CHH}$ gene has occurred before the radiation of decapods and the split between Dendrobranchiata and Pleocyemata, but this node was strongly supported only in the BI analysis (pp of 1.00, bootstrap value of $45 \%$ in the ML analysis).

A clade supported by a bootstrap value of $76 \%$ (pp of 0.99 in $\mathrm{BI}$ ) was positioned at the base of the type I and type II clades and contained all ITPs from insects, together with the peptides characterized in the collembolan Folsomia candida and the branchiopods Daphnia magna and Daphnia pulex, which were located at the base. The type III sub-family was thus created to designate peptides contained in this clade.

Since the topology of this clade was only weakly supported (notably with insects appearing paraphyletic), amino acid and DNA datasets containing less taxa but more characters were used for phylogenetic inference. When an outgroup (DNA or amino acid sequences

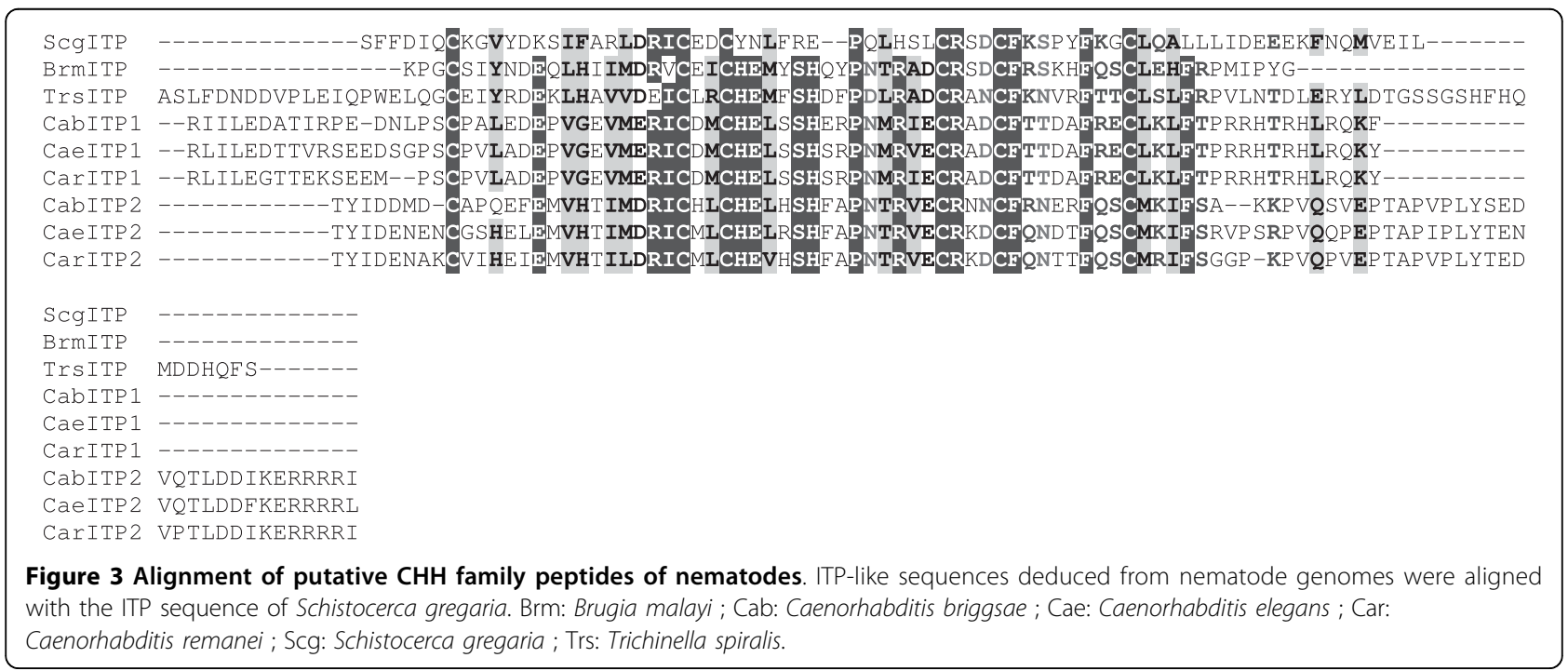




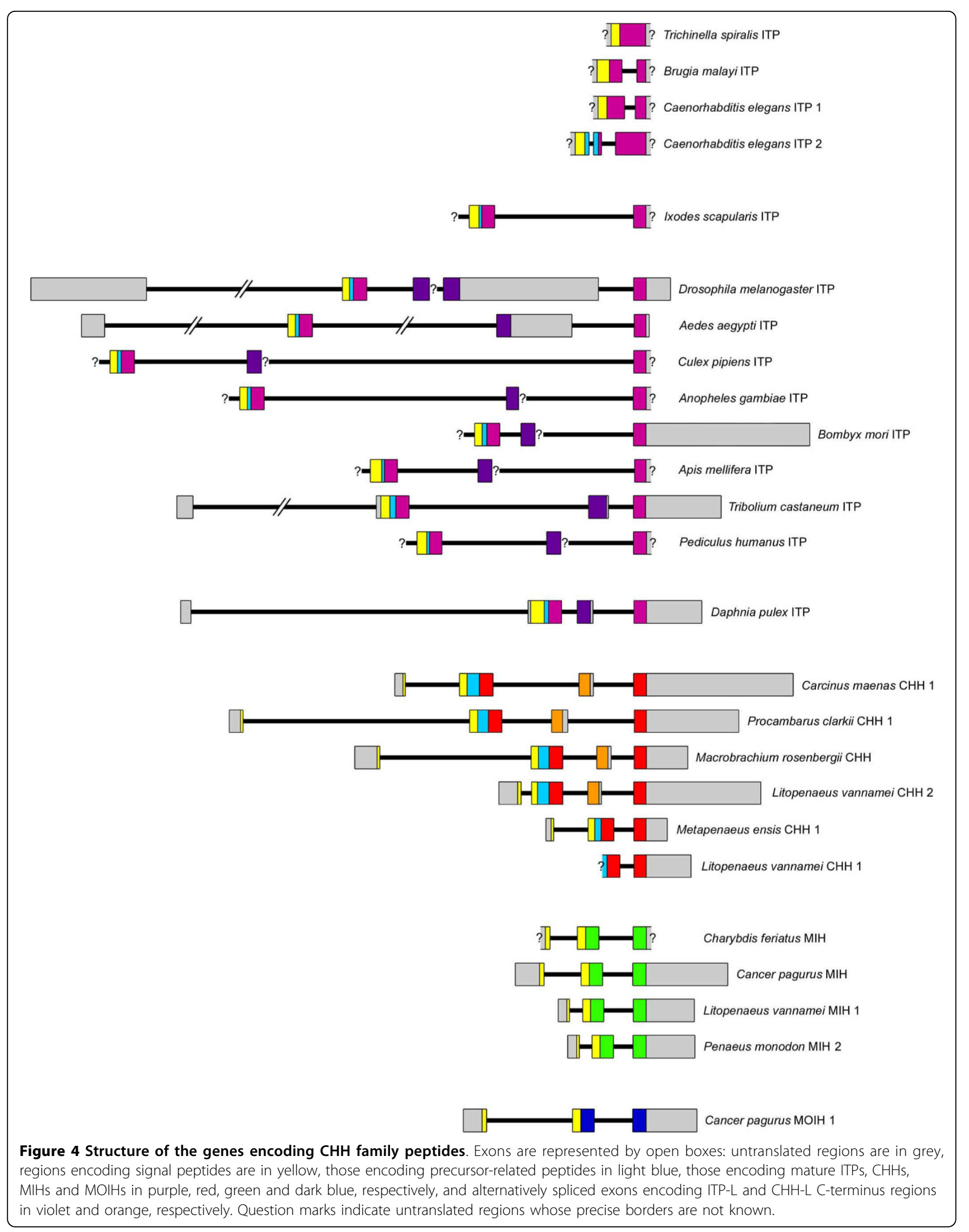




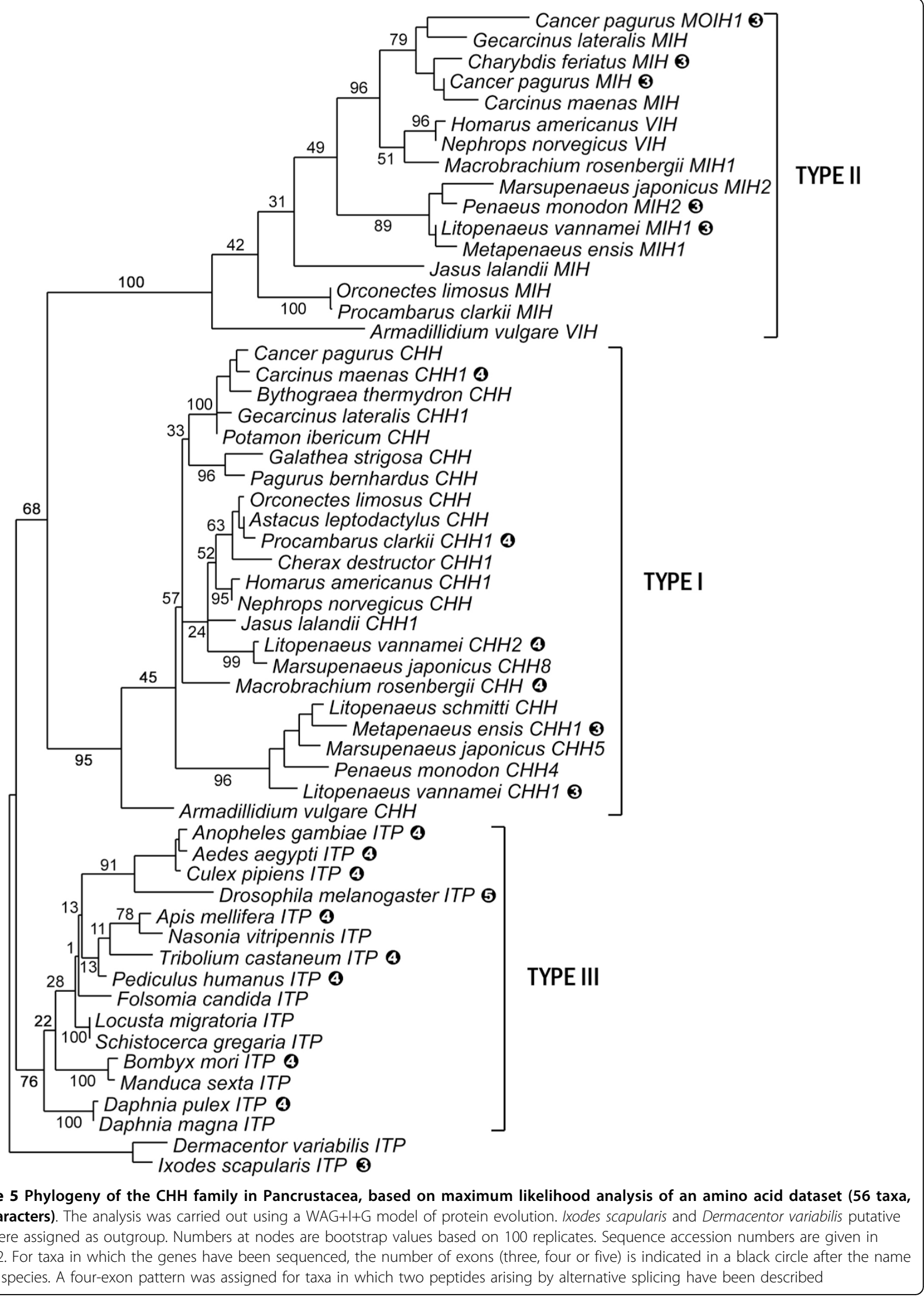


from Ixodes scapularis) was included in these datasets, a structure of two monophyletic groups was found within the ingroup: a "type I" clade (supported by a bootstrap value of $100 \%$ in the ML analysis based on the amino acid dataset and by posterior probabilities of 1.00 in $\mathrm{BI}$ analyses using either amino acid or DNA dataset) and a "type III" clade (bootstrap value of $48 \%$ in the ML analysis of the amino acid dataset, posterior probabilities of 0.79 and 0.98 in BI analyses based on the amino acid and the DNA datasets, respectively). Since the four exons used in these datasets exist only in the ingroup species, the inclusion of the outgroup resulted in a loss of phylogenetic signal. Then, the outgroup was removed for subsequent analyses and the resulting trees were rooted using the structure in two clades previously found.

Phylogenies built from these 23-taxa datasets using ML and BI methods were similar (Figure 6). Insects appeared monophyletic, albeit with moderate support, and the relationships within the insect clade were not resolved. Yet, the collembolan Folsomia candida was positioned at the base of the insects, thus forming a moderately supported monophyletic hexapod clade, and branchiopods were a sister group to hexapods, with high support.

\section{Evolutionary scenarios of the $\mathrm{CHH}$ family genes}

Using the 23-taxa sequence datasets, a $\mathrm{KH}$ test was conducted to decide which of the two competing phylogenetic hypotheses for arthropods presented in Figure 1 could be used to build an evolutionary scenario of the $\mathrm{CHH}$ family. This test clearly supported $(\mathrm{P}<0.0001)$ the tree based on nuclear genes, with a monophyletic Hexapoda sister-group to Branchiopoda (Figure 1B), versus the tree based on mitochondrial genes (Figure 1A). Then, the ML phylogeny of $\mathrm{CHH}$ family peptides (Figure 5) was superimposed on a species tree in which Branchiopoda were sister-group to Hexapoda, to create a topology accounting for gene duplications in Pancrustacea (Figure 7A). In nematodes, a gene duplication was also inferred in the Caenorhabditis phylum, as two paralogs were found in genomes of Caenorhabditis species. In the most parsimonious scenario of

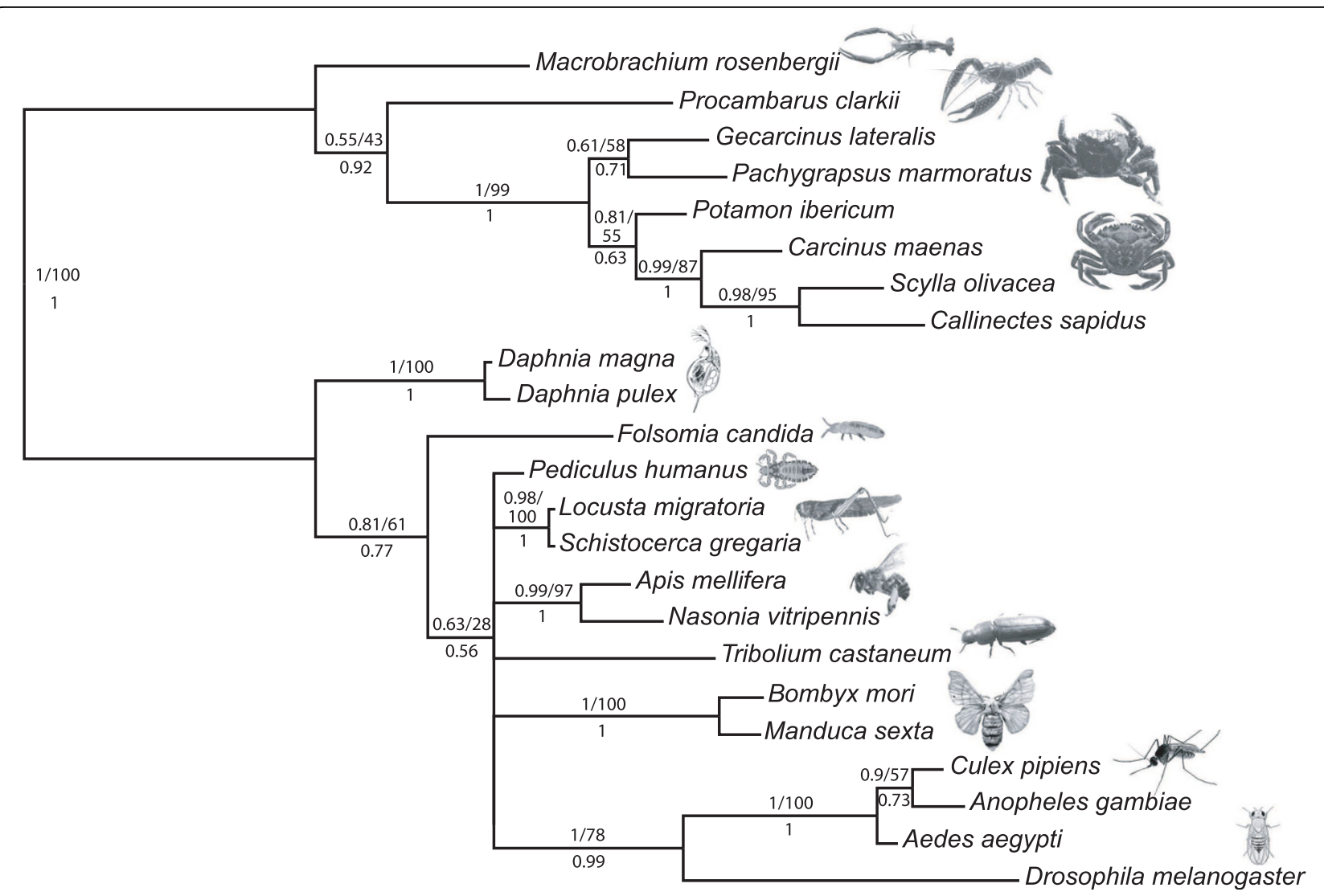

Figure 6 Phylogeny based on Bayesian analysis of the amino acid dataset including CHH-L and ITP-L sequences (23 taxa, 109 characters). Trees obtained by maximum likelihood analysis of the amino acid dataset and by Bayesian analysis of the DNA dataset were fully congruent. Numbers above branches are posterior probabilities and bootstrap values (based on 100 replicates) obtained from the analysis of the amino acid dataset, and numbers below branches are posterior probabilities obtained from the analysis of the DNA dataset. Sequence accession numbers are given in Table 2. 


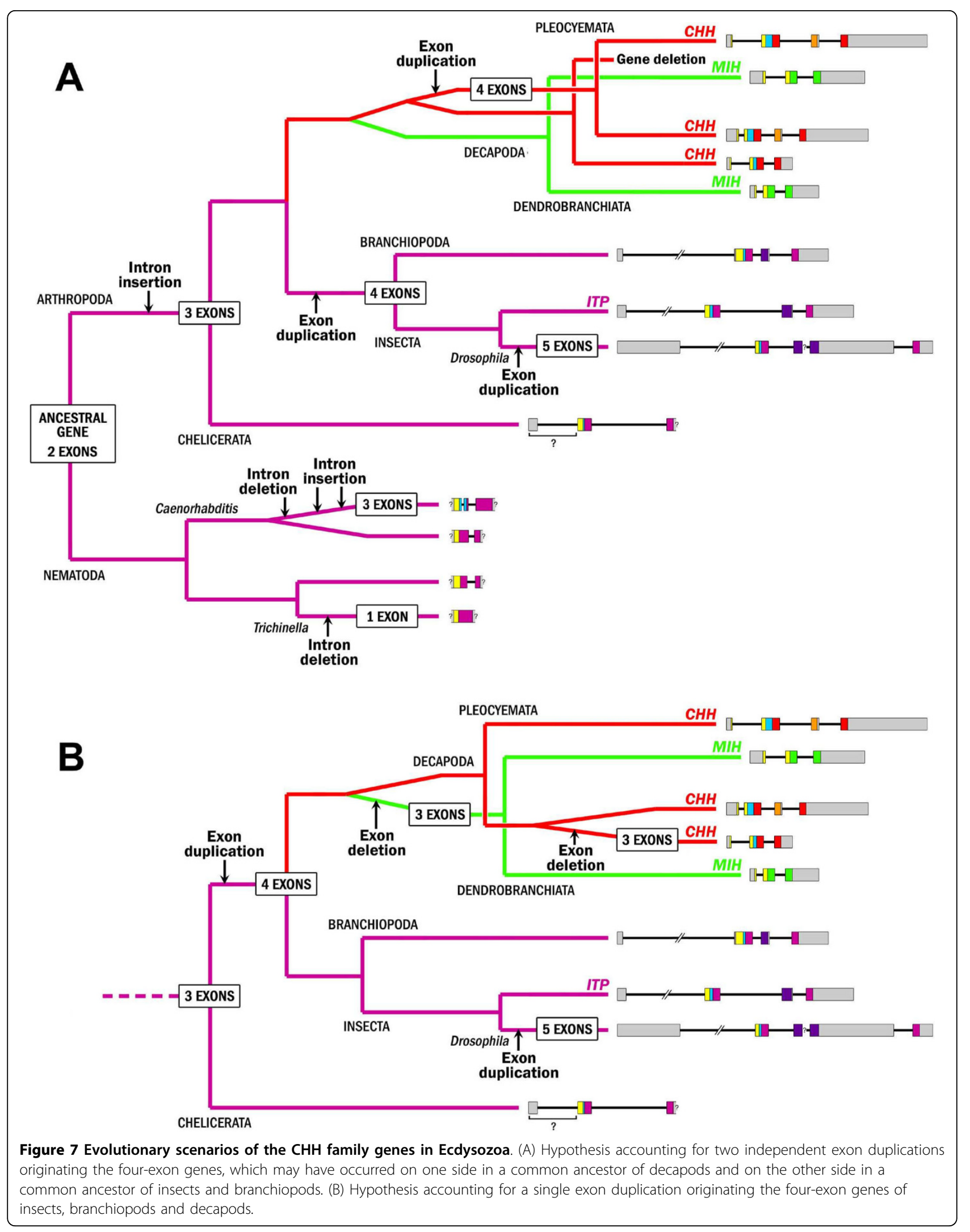


gene structure evolution based on this topology, $\mathrm{CHH}$ family genes of Ecdysozoa evolved from an ancestral twoexon gene, with nine partial insertion or deletion events (Figure 7A).In this scenario, $\mathrm{CHH}$ family genes of arthropods have all evolved from a three-exon gene, and the four-exon gene structure would have appeared independently twice, in a common ancestor of decapods and in a common ancestor of insects and branchiopods.

Because of the weak support, in the ML phylogeny (Figure 5), at the node indicating the duplication which led to the two paralogous $\mathrm{CHH}$ genes found in Dendrobranchiata (with three or four exons), an alternative topology was considered for pancrustacean $\mathrm{CHH}$ family genes, where the $\mathrm{CHH}$ gene duplication would have occurred only in the Dendrobranchiata phylum (Figure 7B). In that case, the most parsimonious scenario implied eight intron or exon insertion/deletion events, and the exon duplication leading to the four-exon gene structure would have occurred only once.

Regardless of the evolutionary scenario considered, the putative ancestral gene was likely composed of two exons and a phase 2 intron interrupting the codon of the amino acid residue following the fourth cysteine of the mature peptide. Such an intron was found in every known CHH family gene, except the ITP2 genes in Caenorhabditis species and the ITP gene of Trichinella spiralis (Figure 4).

Dibasic processing sites used for precursor maturation by prohormone convertase then likely appeared independently twice, in the common ancestor to arthropods on one hand and in the common ancestor to the Caenorhabditis genus on the other hand, leading to the occurrence in these lineages of precursor related peptides (blue boxes in Figures 4 and 7), such as the $\mathrm{CHH}$ precursor related peptides (CPRPs) of decapods.

\section{Discussion}

\section{Evolution of the $\mathrm{CHH}$ family in decapods and functional implications}

Since the discovery of neuroendocrine factors within the eyestalks of decapods seventy years ago [24-26], structural and functional data about $\mathrm{CHH}$ family peptides in these crustaceans have been accumulated. While our knowledge increased, it became more and more difficult to propose a model of endocrine regulation applying to all decapods. Indeed, $\mathrm{CHH}$ family peptides are not identical in all decapod groups, and their function varies with the species. This diversity prompted us to investigate the evolutionary history of these peptides.

In decapods, many gene duplications have occurred, leading to two main paralogous lineages (type I and type II peptides) and to a large polymorphism of $\mathrm{CHH}$ family peptides inside these lineages (Figure 7). For example, two clusters containing each at least 7 different $\mathrm{CHH}$ genes were identified in the shrimp Metapenaeus ensis [27]. A paradigm in evolutionary biology is that gene duplication represents the major mechanism for emergence of new functions, as one of the two copies is potentially freed from selective pressure and will accumulate more mutations during evolution $[28,29]$. In the $\mathrm{CHH}$ family, the functional divergence observed between the two paralogous lineages could result from a subfunctionalization [30,31], rather than from a neofunctionalization. In fact, the ancestral gene may have encoded a pleiotropic hormone, like current $\mathrm{CHH}$, and after duplication of this gene the type II paralogous lineage may have evolved faster to peptides with a $\mathrm{CHH}$-like structure, but devoid of hyperglycemic activity and conversely exhibiting more specialized activities, such as inhibition of molting or vitellogenesis (for MIHs and VIHs, respectively). The faster evolution rate of type II peptide genes may explain the loss of phylogenetic signal observed in MIHs, VIHs and MOIHs sequences. Indeed, the topology of the "type II" clade (Figure 5) is not congruent with the phylogeny of decapods, whereas it is for the "type I" clade, as shown in earlier work [11]. This clearly impedes the elucidation of evolutionary relationships between type II peptides. The only paralogous lineages clearly identified so far are the MIHs and MOIHs of Cancer crabs, as the MOIH genes seem to have appeared from a duplicated MIH gene only in this genus [32]. In lobsters, there is no MIH identified so far but a VIH instead, whose gene may have evolved from a MIH gene subjected to a reduced selective pressure, as molt inhibition is exerted in this taxa by a $\mathrm{CHH}$ isoform [33].

\section{Evolutionary history "outside decapods"}

A high number of gene duplications were observed in decapods only. So far, the only paralogous lineages identified outside decapods are the "ITP1" and "ITP2" genes found in Caenorhabditis species (Figure 7), and only one $\mathrm{CHH}$ family peptide gene could be found in genomes of the other nematodes, the insects and the deer tick. In the water flea Daphnia pulex, one ITP gene was also rebuilt from whole genome shotgun (WGS) sequences but other WGS sequences sharing sequence identity with the ITP gene have been found. However, it is unclear whether these sequences correspond to another $\mathrm{CHH}$ family peptide coding gene or to a pseudo-gene: this gene would have a peculiar structure, with exon III lacking, and the prepro-peptide putatively encoded would lack the dibasic processing site found in every $\mathrm{CHH}$ or ITP precursors and the 6 following residues of the mature peptide as well. Yet, although only one ITP and one ITP-L cDNA have been cloned in Daphnia magna, recently published EST data suggest that both genes may be expressed in Daphnia pulex [34], but EST and genomic sequences do not match 
(only $85 \%$ identity between deduced amino acid sequences). To include these data in an evolutionary scenario, genomic and mRNA sequences should be characterized by molecular cloning.

This apparent lack of paralogous lineages outside decapods raises the question of a possible conservation of function between the ITPs of insects and the related peptides found in branchiopods, chelicerates and nematodes. Yet, functional studies are too scarce to address this question. In insects, the effect of ITP on ionic and water balance was only demonstrated in locusts $[35,36]$ and nothing is known about the function of ITP-like peptides in chelicerates or nematodes. In branchiopods, only one gene expression study on sex determination in Daphnia magna has indicated that $\mathrm{CHH}$ family peptides may inhibit methyl farnesoate synthesis by the mandibular organ [37]. It is noteworthy that several $\mathrm{CHH}$ family peptides are known to play such a role in decapods [38-40]. It will be informative to determine whether Daphnia peptides exhibit other typical "decapod" functions such as hyperglycemia or ecdysteroid synthesis inhibition, or if they also possess an anti-diuretic activity, as shown for insect ITPs. A similar question about another neuropeptide family, the $\mathrm{RPCH} / \mathrm{AKH}$ family, has recently found a partial answer. Like for the $\mathrm{CHH}$ family, the putative RPCH (red pigment-concentrating hormone) of Daphnia magna shares more sequence similarity with AKHs (adipo-kinetic hormones) of insects than with $\mathrm{RPCH}$ of decapod crustaceans [41]. In a heterologous bioassay, this peptide was able to trigger a mobilization of lipid reserves when injected into the green shield bug Nezara viridula whereas it did not provoke pigment migration when injected into the shrimp Palaemon pacificus [42]. Although heterologous bioassays must be considered cautiously, such results suggest that this peptide could have an adipokinetic function in water fleas (like in insects) rather than a pigment-concentration function (like in decapods).

\section{Emergence of the four-exon genes}

One important step in the evolution of the $\mathrm{CHH}$ family is the emergence of the four-exon genes found in decapods, branchiopods and insects. In these genes, exons III and IV encode peptide sequences of similar lengths, with two cystein residues in the same positions, thus suggesting that the supplementary exon has appeared by tandem duplication of another exon. At first glance, it seems more likely that this duplication has occurred only once, in a common ancestor of Pancrustacea (Figure 7B). In all these taxa, two peptides are produced by alternative splicing; one peptide ( $\mathrm{CHH}$ or ITP) is 72 or 73 amino acids long and is always amidated on its $\mathrm{C}$-terminal end, and the other peptide (CHH-L or ITP-L) is slightly longer and is never amidated. Moreover, the expression of these two isoforms seems to be similar in decapods and insects; in the crab Carcinus maenas and the caridean shrimp Macrobrachium rosenbergii, $\mathrm{CHH}$ transcripts were mainly found in neurons of the central nervous system (more precisely in the $\mathrm{X}$-organ located in the eyestalk) whereas $\mathrm{CHH}-\mathrm{L}$ transcripts were found in neurons of the peripheral nervous system [7,8]; in the moths Manduca sexta and Bombyx mori and the locust Schistocerca americana, ITP-immunoreactive neurons were only found in the brain, whereas ITP-L-immunoreactive ones were found along the ventral nervous chain. ITP-L immunoreactivity was also detected in the brain, but was weak and restricted to cell bodies, thus suggesting that ITP-L was not secreted from this tissue [43].

Yet, even if the hypothesis of an independent emergence of the fourth exon (Figure 7A) appears unlikely, it should not be rejected, as a similar exon duplication also occurred in a Drosophila ancestor, leading to the five-exon gene found in Drosophila melanogaster [44].

\section{Controversy about pancrustacean phylogeny}

Given the relative short length of the sequences used, the objective of this study was not to build a phylogeny of pancrustaceans using $\mathrm{CHH}$ family peptides, but to choose the appropriate phylogeny to infer evolutionary scenarios of the $\mathrm{CHH}$ family. The $\mathrm{KH}$ test carried out with our datasets indicated a congruence of the data with recent molecular phylogenies of pancrustaceans based on nuclear gene sequences [21-23] and not with those based on mitochondrial genes [18-20]. Moreover, the robustness and quality of the signal contained in mitochondrial gene sequences for arthropod phylogenetics have recently been questioned $[45,46]$. Supplementary taxa will have to be represented within $\mathrm{CHH}$ family datasets to confirm this result, but studying the evolutionary history of this family may help to select synapomorphies to support concurrent phylogenetic hypotheses about pancrustacean relationships. For example, the presence of paralogous type I and type II peptides could constitute a trait shared by malacostracans and their sister-groups.

\section{Conclusion}

The evolutionary scenarios proposed in this study suggest that genes encoding Crustacean Hyperglycemic Hormone family peptides of Ecdysozoa evolved from an ancestral two-exon gene. In the malacostracan lineage (including decapods), the evolution of the $\mathrm{CHH}$ family has involved numerous duplications, insertions and deletions of exons or entire genes, leading to the wide variety of functions displayed by the encoded neurohormones in decapods. This neuropeptide family could thus constitute a promising model to investigate the evolutionary forces at the root of the functional divergence of duplicated 
genes. Outside malacostracans, the number of gene duplications seems to have been lower, which may reflect different evolutionary pathways. At present, $\mathrm{CHH}$ family peptides characterized outside decapods are still scarce, and this work constitutes a first step in a wider quest. In the future, the evolutionary scenarios elaborated here will be completed and amended, as $\mathrm{CHH}$ family peptides will probably be characterized in new taxa. The 38 genome sequencing projects currently under way in ecdysozoan species will be of valuable help as soon as they are completed, to enlarge our view on the evolution of this multigenic family.

\section{Methods}

\section{Biological material and RNA extraction}

Daphnia magna and Folsomia candida (strain TO) specimens were supplied by the BIOEMCO laboratory and the Ecology \& Evolution laboratory, respectively, both located at the Ecole Normale Supérieure (Paris, France). Total RNA was extracted from $10 \mathrm{mg}$ of whole animals, using SV Total RNA Isolation System (Promega, Madison, WI). cDNA was synthesized from 300 ng of total RNA using 200 U of M-MLV Reverse Transcriptase (Promega), 20 pmoles of each dNTP and 30 pmoles of an Oligo(dT) primer. This synthesis was performed at $42^{\circ} \mathrm{C}$ for 1 hour, followed by an inactivation step at $70^{\circ} \mathrm{C}$ for $15 \mathrm{~min}$.

\section{PCR amplification and cloning}

First, a central region of putative ITP precursor cDNAs was amplified using degenerate primers DgnITP-Up (5'-CTTCGAYATCMAKTGYAARGG-3') and DgnITPDown (5'-RAGRCAWCCTTTGAAGWATG-3') designed from the alignment of known insect ITP cDNAs. The reaction mixture contained $1.5 \mathrm{U}$ of GoTaq ${ }^{\circledR}$ DNA Polymerase (Promega), 5 pmoles of each dNTP and 10 pmoles of each degenerate primer. Amplifications were conducted with a denaturation step at $94^{\circ} \mathrm{C}$ for $3 \mathrm{~min}$, followed by 40 cycles of $94^{\circ} \mathrm{C}$ for $30 \mathrm{sec}, 55^{\circ} \mathrm{C}$ for $30 \mathrm{sec}$ and $72^{\circ} \mathrm{C}$ for $30 \mathrm{sec}$, and a final extension step at $72^{\circ} \mathrm{C}$ for $10 \mathrm{~min}$. After their purification with the Wizard ${ }^{\circledR} \mathrm{SV}$ Gel and PCR Clean-Up System (Promega), products were cloned using pGEM $^{\oplus}$ - T Easy Vector and JM109 Competent Cells (Promega). Plasmids were purified using the Wizard $^{\oplus}$ Plus SV Minipreps DNA Purification System (Promega), and their sequencing was performed by Cogenics - Genome Express (Meylan, France).

\section{$3^{\prime}$ and 5'RACE}

To create cDNAs which contain a synthetic adaptor either at the 5' or 3' end, total RNA was reverse-transcribed using the SMART ${ }^{\mathrm{TM}}$ RACE cDNA Amplification Kit (Clontech, Moutain View, CA). For PCR amplifications, two sets of primers, specific of Daphnia magna and Folsomia candida, were designed from the partial
cDNA sequences obtained by RT-PCR. These primers are listed in Table 1. First amplifications were performed using the adaptor primer supplied with the kit (Universal Primer Mix) and specific primers Up1 (for 3'RACE) or Down1 (for 5'RACE). Then, nested PCRs were performed on $1 / 150^{\text {th }}$ of the first PCR products, between the Nested Universal Primer from the kit and specific primers Up2 or Down2. All reverse-transcription and PCR amplification steps were carried out following the protocol supplied in the kit. RACE products were cloned and sequenced as described above.

\section{Database mining}

A search for $\mathrm{CHH}$ family peptide sequences from arthropods and nematodes was performed with the BLAST program at the NCBI website http://blast.ncbi. nlm.nih.gov/Blast.cgi. The non-redundant protein sequences $(\mathrm{nr})$ database was mined by blastp algorithm using Schistocerca gregaria ITP or the putative peptide ZC168.2 of Caenorhabditis elegans as query sequences for arthropods and for nematodes, respectively. Corresponding mRNA sequences were also collected, and aligned with genome sequences to determine the exonintron structure of the genes. Sequences of genes encoding putative $\mathrm{CHH}$ family peptides of Daphnia pulex (Branchiopoda), Ixodes scapularis (Chelicerata), Caenorhabditis remanei and Brugia malayi (Nematoda) were assembled from whole genome shotgun (WGS) sequences available in the NCBI Trace Archives database, by assembling trace reads with CLC Genomics Workbench software (CLCbio, Aarhus, Denmark).

\section{Phylogenetic analyses}

Datasets containing mature $\mathrm{CHH}$ family peptide sequences and the corresponding DNA sequences

Table 1 Primers used for $3^{\prime}$ and 5'RACE.

\begin{tabular}{llll}
\hline Primer & Species & Sequence $\left(5^{\prime}\right.$ to $\left.3^{\prime}\right)$ & $\begin{array}{l}\mathrm{Tm} \\
\left({ }^{\circ} \mathrm{C}\right)\end{array}$ \\
\hline DamITP-Up1 & $\begin{array}{l}\text { Daphnia } \\
\text { magna } \\
\text { Daphnia } \\
\text { DamITP-Up2 }\end{array}$ & TCCAGCGGCCATCATTCGTTGTCC & 71 \\
DamITP-Down1 & $\begin{array}{l}\text { Daphnia } \\
\text { magna }\end{array}$ & GGACAACGAATGATGGCCGCTGGA & 71 \\
DamITP-Down2 & $\begin{array}{l}\text { Daphnia } \\
\text { magna }\end{array}$ & ACTGGGAAGCACTGCGAGCAAAACC & 72 \\
FocITP-Up1 & $\begin{array}{l}\text { Folsomia } \\
\text { candida }\end{array}$ & GCCAAGCTGGACAGAATTGCGACGAT & 73 \\
FocITP-Up2 & $\begin{array}{l}\text { Folsomia } \\
\text { candida }\end{array}$ & ACAACTCCACTCGCTATGCAGGTCGAA & 73 \\
FocITP-Down1 & $\begin{array}{l}\text { Folsomia } \\
\text { candida }\end{array}$ & TTCGACCTGCATAGCGAGTGGAGTGT & 73 \\
FocITP-Down2 & $\begin{array}{l}\text { Folsomia } \\
\text { candida }\end{array}$ & ATCGTCGCAAATTCTGTCCAGCTTGGC & 73 \\
\hline
\end{tabular}


(when available) from Pancrustacea were created. In the amino acid dataset, 37 sequences from decapods (22 $\mathrm{CHH}$ and $15 \mathrm{MIH}, \mathrm{VIH}$ or $\mathrm{MOIH}$ ) were selected among the 90 available sequences, and added to the 17 sequences from hexapods and branchiopods. ITP-like sequences of the ticks Ixodes scapularis and Dermacentor variabilis were included to be used as outgroup (for sequence references, see Table 2). Alignments were performed manually with Se-Al v2.0a11 http://tree.bio.ed. ac.uk/software/seal/, and after removal of N-terminal and $\mathrm{C}$-terminal unconserved residues, the dataset contained 56 taxa and 73 characters. The DNA dataset contained 49 taxa and 219 characters.

DNA and amino acid datasets including $\mathrm{CHH}-\mathrm{L}$ and ITP-L sequences were also created. For the 23 taxa in which such peptides are known, the amino acid sequence of the mature $\mathrm{CHH}-\mathrm{L}$ or ITP-L (encoded by exons II and III of the gene) was concatenated with the C-terminal sequence of $\mathrm{CHH}$ or ITP (encoded by exon IV of the gene). Alignments were performed manually and 109 unambiguously aligned residues were conserved in the dataset. The DNA dataset contained 327 characters.

At first, DNA and translated amino acid sequences of Ixodes scapularis ITP-like were included in these datasets, to be used as an outgroup in order to determine the global branching order in the ingroup. Since the gene encoding this peptide lacks exon III in the outgroup taxon, corresponding characters were replaced with "?" symbols in the alignments. Because of the loss of phylogenetic signal brought by the inclusion of the outgroup, it was removed from datasets for subsequent phylogenetic analyses, but the global structure previously found was kept.

Phylogenetic reconstructions were carried out using Bayesian inference and maximum likelihood. Bayesian analyses were performed with MrBayes 3.1.2 with four chains of $10^{6}$ generations, trees sampled every 100 generations and burn-in value set to $20 \%$ of the sampled trees. We checked that standard deviation of the split frequencies fell below 0.01 to insure convergence in tree search. Protein sequences were analyzed with a mixed amino acid model [47], and DNA sequences were considered with an evolutionary model designed for coding sequences and taking the genetic code into account [48-50].

Maximum likelihood reconstructions were carried out only on amino acid sequences. For both datasets, the WAG+I+G substitution model [51] was determined as the best-fit model of protein evolution by ProtTest 1.3 [52]http://darwin.uvigo.es/software/prottest_server.html, following Akaike Information Criterion. Rate heterogeneity was set at four categories. The gamma distribution parameter and the proportion of invariable sites were
Table 2 Amino acid sequences used for phylogenetic inference.

\begin{tabular}{|c|c|c|}
\hline Species & Peptide & Accession number \\
\hline \multicolumn{3}{|l|}{ Chelicerata } \\
\hline \multicolumn{3}{|l|}{ Arachnida } \\
\hline Dermacentor variabilis & ITP & ACC99599 \\
\hline Ixodes scapularis & ITP & (1) \\
\hline \multicolumn{3}{|l|}{$\underline{\text { Hexapoda }}$} \\
\hline \multicolumn{3}{|l|}{ Collembola } \\
\hline \multirow[t]{2}{*}{ Folsomia candida } & ITP & ACF15252 \\
\hline & ITP-L & ACJ01668 \\
\hline
\end{tabular}

Insecta

\begin{tabular}{|c|c|c|}
\hline \multirow[t]{2}{*}{ Aedes aegypti } & ITP & AAY29661 \\
\hline & ITP-L & AAY29663 \\
\hline \multirow[t]{2}{*}{ Anopheles gambiae } & ITP & (1) \\
\hline & ITP-L & XP_313928 \\
\hline \multirow[t]{2}{*}{ Apis mellifera } & ITP & XP_001120062 \\
\hline & ITP-L & (1) \\
\hline \multirow[t]{2}{*}{ Bombyx mori } & ITP & AAY29659 \\
\hline & ITP-L & AAY29660 \\
\hline \multirow[t]{2}{*}{ Culex pipiens } & ITP & (1) \\
\hline & ITP-L & XP_001845654 \\
\hline \multirow[t]{2}{*}{ Drosophila melanogaster } & ITP & ABZ88142 \\
\hline & ITP-L 2 & ABZ88141 \\
\hline \multirow[t]{2}{*}{ Locusta migratoria } & ITP & AAD20820 \\
\hline & ITP-L & AAD20821 \\
\hline \multirow[t]{2}{*}{ Manduca sexta } & ITP & AAY29657 \\
\hline & ITP-L & AAY29658 \\
\hline \multirow[t]{2}{*}{ Nasonia vitripennis } & ITP & (1) \\
\hline & ITP-L & XP_001604056 \\
\hline \multirow[t]{2}{*}{ Pediculus humanus } & ITP & (1) \\
\hline & ITP-L & EEB14555 \\
\hline \multirow[t]{2}{*}{ Schistocerca gregaria } & ITP & AAB16822 \\
\hline & ITP-L & AAB16823 \\
\hline \multirow[t]{2}{*}{ Tribolium castaneum } & ITP & ABN79658 \\
\hline & ITP-L & ABN79657 \\
\hline
\end{tabular}

Branchiopoda

Daphnia magna

ITP

ITP-L ABO43964

Daphnia pulex

ITP

(1)

ITP-L (1)

\begin{tabular}{lll}
$\frac{\text { Malacostraca }}{\text { Isopoda }}$ & & \\
\hline Armadillidium vulgare & $\mathrm{CHH}$ & $\mathrm{P} 30814$ \\
& $\mathrm{VIH}$ & $\mathrm{P} 83627$
\end{tabular}

\section{Decapoda}

Astacus leptodactylus $\quad$ CHH $\quad$ AAX09331

Bythograea thermydron $\quad \mathrm{CHH} \quad$ AAK28329 
Table 2: Amino acid sequences used for phylogenetic inference. (Continued)

\begin{tabular}{|c|c|c|}
\hline \multirow[t]{2}{*}{ Callinectes sapidus } & $\mathrm{CHH}$ & AAS45136 \\
\hline & $\mathrm{CHH}-\mathrm{L}$ & ABC61678 \\
\hline \multirow[t]{3}{*}{ Cancer pagurus } & $\mathrm{CHH}$ & P81032 \\
\hline & $\mathrm{MIH}$ & CAC05346 \\
\hline & MOIH 1 & CAB61424 \\
\hline \multirow[t]{3}{*}{ Carcinus maenas } & $\mathrm{CHH} 1$ & AAG29429 \\
\hline & $\mathrm{CHH}-\mathrm{L} 1$ & AAG29432 \\
\hline & $\mathrm{MIH}$ & Q27225 \\
\hline Charybdis feriatus & $\mathrm{MIH}$ & 096605 \\
\hline Cherax destructor & $\mathrm{CHH} 1$ & P83485 \\
\hline Galathea strigosa & $\mathrm{CHH}$ & ABS01332 \\
\hline \multirow[t]{3}{*}{ Gecarcinus lateralis } & $\mathrm{CHH} 1$ & ABF48652 \\
\hline & $\mathrm{CHH}-\mathrm{L}$ & ABF58091 \\
\hline & $\mathrm{MIH}$ & ABF06632 \\
\hline \multirow[t]{2}{*}{ Homarus americanus } & $\mathrm{CHH} 1$ & P19806 \\
\hline & $\mathrm{VIH}$ & P55320 \\
\hline \multirow[t]{2}{*}{ Jasus lalandii } & $\mathrm{CHH} 1$ & P56687 \\
\hline & $\mathrm{MIH}$ & P83220 \\
\hline Litopenaeus schmitti & $\mathrm{CHH}$ & P59685 \\
\hline \multirow[t]{3}{*}{ Litopenaeus vannamei } & $\mathrm{CHH} 1$ & Q26181 \\
\hline & $\mathrm{CHH} 2$ & {$[56]$} \\
\hline & MIH 1 & ABD73291 \\
\hline \multirow[t]{3}{*}{ Macrobrachium rosenbergii } & $\mathrm{CHH}$ & AAL40915 \\
\hline & $\mathrm{CHH}-\mathrm{L}$ & AAL40916 \\
\hline & MIH 1 & AAL37948 \\
\hline \multirow[t]{3}{*}{ Marsupenaeus japonicus } & $\mathrm{CHH} 5$ & 015981 \\
\hline & $\mathrm{CHH} 8$ & (1) \\
\hline & $\mathrm{MlH} 2$ & BAD36757 \\
\hline \multirow[t]{2}{*}{ Metapenaeus ensis } & $\mathrm{CHH} 1$ & AAD11813 \\
\hline & MIH 1 & O76534 \\
\hline \multirow[t]{2}{*}{ Nephrops norvegicus } & $\mathrm{CHH}$ & AAQ22391 \\
\hline & $\mathrm{VIH}$ & AAK58133 \\
\hline \multirow[t]{2}{*}{ Orconectes limosus } & $\mathrm{CHH}$ & Q25589 \\
\hline & $\mathrm{MIH}$ & P83636 \\
\hline \multirow[t]{2}{*}{ Pachygrapsus marmoratus } & $\mathrm{CHH}$ & AAO27804 \\
\hline & $\mathrm{CHH}-\mathrm{L}$ & AAO27806 \\
\hline Pagurus bernhardus & $\mathrm{CHH}$ & ABE02191 \\
\hline \multirow[t]{2}{*}{ Penaeus monodon } & $\mathrm{CHH} 4$ & 097386 \\
\hline & $\mathrm{MlH} 2$ & AAR89517 \\
\hline \multirow[t]{2}{*}{ Potamon ibericum } & $\mathrm{CHH}$ & ABA70560 \\
\hline & $\mathrm{CHH}-\mathrm{L}$ & ABA70561 \\
\hline Procambarus bouvieri & $\mathrm{CHH} 2$ & Q10987 \\
\hline \multirow[t]{3}{*}{ Procambarus clarkii } & $\mathrm{CHH} 1$ & BAA89003 \\
\hline & $\mathrm{CHH}-\mathrm{L} 1$ & AAL79193 \\
\hline & $\mathrm{MIH}$ & P55848 \\
\hline \multirow[t]{2}{*}{ Scylla olivacea } & $\mathrm{CHH}$ & AAQ75760 \\
\hline & $\mathrm{CHH}-\mathrm{L}$ & ABP88270 \\
\hline
\end{tabular}

(1) Sequences deduced from genomic sequences or from the alternatively spliced product estimated from the datasets. Tree reconstructions were performed using PhyML 3.0 [53]http://www.atgc-montpellier.fr/phyml/ and validated with 100 bootstrap replicates.

\section{Evolutionary scenarios}

The two phylogenetic trees shown in Figure 1 were used as competing hypotheses to assess if one was more strongly supported by the 23-taxa sequence datasets. This was done via a $\mathrm{KH}$ test using a maximum likelihood criterion [54]. This allowed us to choose a "species tree" on which the "gene tree" could be super-imposed.

The evolution of $\mathrm{CHH}$ family gene structures was analyzed using Mesquite 2.6 [55], under a parsimony framework. For this analysis, two alternate topologies depicting the evolution of the $\mathrm{CHH}$ family genes were created. All the known intron locations within $\mathrm{CHH}$ family genes were considered as characters and the presence/absence of intron in each location was coded 0 (absence) or 1 (presence) to create a character matrix.

\section{Acknowledgements}

The authors are grateful to Drs Gérard Lacroix, Michaël Danger and Thomas Tully (Ecole Normale Supérieure, Paris) for supplying water fleas and springtails, and to Drs Laurence Dinan and Stéphane Hourdez for critical reading of the manuscript.

\section{Author details}

'UPMC Univ Paris 06, UMR A 1272 INRA - Physiologie de I'Insecte: Signalisation et Communication, F-75005, Paris, France. 2UPMC Univ Paris 06, FRE 3247 CNRS - Modèles en Biologie Cellulaire et Évolutive, Observatoire Océanologique, F-66651, Banyuls-sur-Mer, France. ${ }^{3}$ UPMC Univ Paris 06, ER3 Biogenèse des Signaux Peptidiques, F-75005, Paris, France. ${ }^{4}$ UPMC Univ Paris 06, UMR 7144 CNRS - Adaptation et Diversité en Milieu Marin, Station Biologique de Roscoff, F-29682, Roscoff, France.

\section{Authors' contributions}

NM carried out molecular cloning, database mining, sequence alignments and drafted the manuscript. YD performed phylogenetic analyses and edited the manuscript. DS participated in the design of the study and edited the manuscript. JYT designed and coordinated the study and helped to draft the manuscript. All authors read and approved the final manuscript.

Received: 25 September 2009

Accepted: 25 February 2010 Published: 25 February 2010

\section{References}

1. Angelini DR, Kaufman TC: Comparative developmental genetics and the evolution of arthropod body plans. Annu Rev Genet 2005, 39:95-119.

2. Böcking $D$, Dircksen $H$, Keller R: The crustacean neuropeptides of the CHH/MIH/GIH family: structures and biological activities. The Crustacean Nervous System Berlin, Heidelberg, New York: SpringerWiese K 2002, 84-97.

3. Chen SH, Lin CY, Kuo CM: In silico analysis of crustacean hyperglycemic hormone family. Mar Biotechnol (NY) 2005, 7(3):193-206.

4. Soyez D: Recent data on the crustacean hyperglycemic hormone family. Recent Advances in Marine Biotechnology Plymouth, U.K.: Science PublishersFingerman M, Nagabhushanam R 2003, 10:279-301.

5. Lacombe C, Grève P, Martin G: Overview on the sub-grouping of the crustacean hyperglycemic hormone family. Neuropeptides 1999, 33(1):71-80. 
6. Fanjul-Moles ML: Biochemical and functional aspects of crustacean hyperglycemic hormone in decapod crustaceans: review and update. Comp Biochem Physiol C Toxicol Pharmacol 2006, 142(3-4):390-400

7. Chen $\mathrm{SH}$, Lin CY, Kuo CM: Cloning of two crustacean hyperglycemic hormone isoforms in freshwater giant prawn (Macrobrachium rosenbergii): evidence of alternative splicing. Mar Biotechnol (NY) 2004, 6(1):83-94

8. Dircksen H, Böcking D, Heyn U, Mandel C, Chung JS, Baggerman G, Verhaert P, Daufeldt S, Plosch T, Jaros PP, et al: Crustacean hyperglycaemic hormone $(\mathrm{CHH})$-like peptides and $\mathrm{CHH}$-precursor-related peptides from pericardial organ neurosecretory cells in the shore crab, Carcinus maenas, are putatively spliced and modified products of multiple genes. Biochem J 2001, 356(1):159-170.

9. Tiu SH, He JG, Chan SM: The LvCHH-ITP gene of the shrimp (Litopenaeus vannamei) produces a widely expressed putative ion transport peptide (LvITP) for osmo-regulation. Gene 2007, 396(2):226-235.

10. Webster SG: Neuropeptides inhibiting growth and reproduction in crustaceans. Recent Advances in Arthropod Endocrinology Cambridge, U.K.: Cambridge University PressCoast GM, Webster SG 1998, 33-52.

11. Montagné N, Soyez D, Gallois D, Ollivaux C, Toullec JY: New insights into evolution of crustacean hyperglycaemic hormone in decapods - first characterization in Anomura. FEBS J 2008, 275(5):1039-1052.

12. Grève $P$, Sorokine $O$, Berges $T$, Lacombe $C$, Van Dorsselaer A, Martin G Isolation and amino acid sequence of a peptide with vitellogenesis inhibiting activity from the terrestrial isopod Armadillidium vulgare (Crustacea). Gen Comp Endocrinol 1999, 115(3):406-414

13. Martin G, Sorokine O, Van Dorsselaer A: Isolation and molecular characterization of a hyperglycemic neuropeptide from the sinus gland of the terrestrial isopod Armadillidium vulgare (Crustacea). Eur I Biochem 1993, 211(3):601-607.

14. Dircksen $\mathrm{H}$ : Insect ion transport peptides are derived from alternatively spliced genes and differentially expressed in the central and peripheral nervous system. J Exp Biol 2009, 212(3):401-412.

15. Zhang $\mathrm{Q}$, Keller R, Dircksen $\mathrm{H}$ : Crustacean hyperglycaemic hormone in the nervous system of the primitive crustacean species Daphnia magna and Artemia salina (Crustacea: Branchiopoda). Cell Tiss Res 1997, 287(3):565-576.

16. Laverdure AM, Carette-Desmoucelles C, Breuzet M, Descamps M: Neuropeptides and related nucleic acid sequences detected in peneid shrimps by immunohistochemistry and molecular hybridizations. Neuroscience 1994, 60(2):569-579.

17. Stockmann R, Laverdure AM, Breuzet M: Localization of a crustacean hyperglycemic hormone-like immunoreactivity in the neuroendocrine system of Euscorpius carpathicus (L.) (Scorpionida, Chactidae). Gen Comp Endocrinol 1997, 106(3):320-326.

18. Carapelli A, Liò P, Nardi F, Wath van der E, Frati F: Phylogenetic analysis of mitochondrial protein coding genes confirms the reciprocal paraphyly of Hexapoda and Crustacea. BMC Evol Biol 2007, 7(suppl2 S8):2-13.

19. Cook $C E$, Yue Q, Akam M: Mitochondrial genomes suggest that hexapods and crustaceans are mutually paraphyletic. Proc $R$ SOC B 2005, 272:1295-1304.

20. Hassanin A: Phylogeny of Arthropoda inferred from mitochondria sequences: strategies for limiting the misleading effects of multiple changes in pattern and rates of substitution. Mol Phylogenet Evol 2006, 38:100-106.

21. Mallatt J, Giribet G: Further use of nearly complete $28 \mathrm{~S}$ and $18 \mathrm{~S}$ rRNA genes to classify Ecdysozoa: 37 more arthropods and a kinorhynch. Mol Phylogenet Evol 2006, 40:772-794.

22. Timmermans MJ, Roelofs D, Marien J, van Straalen NM: Revealing pancrustacean relationships: phylogenetic analysis of ribosomal protein genes places Collembola (springtails) in a monophyletic Hexapoda and reinforces the discrepancy between mitochondrial and nuclear DNA markers. BMC Evol Biol 2008, 8:83.

23. Regier JC, Shultz JW, Kambic RE: Pancrustacean phylogeny: hexapods are terrestrial crustaceans and maxillopods are not monophyletic. Proc $R$ Soc B 2005, 272:395-401.

24. Abramowitz RK, Abramowitz AA: Moulting, growth, and survival after eyestalk removal in Uca pugilator. Biol Bull 1940, 78:179-188.

25. Brown FA, Cunningham O: Influence of the sinusgland of crustaceans on normal viability and ecdysis. Biol Bull 1939, 77:104-114.
26. Smith Rl: Studies on the effects of eyestalk removal upon young crayfish (Cambarus clarkii, Girard). Biol Bull 1940, 79:145-152.

27. Gu PL, Yu KL, Chan SM: Molecular characterization of an additional shrimp hyperglycemic hormone: cDNA cloning, gene organization, expression and biological assay of recombinant protein. FEBS Lett 2000, 472:122-128

28. Ohno S: Evolution by Gene Duplication. Berlin, Heidelberg New York: Springer-Verlag 1970.

29. Zhang J: Evolution by gene duplication: an update. Trends Ecol Evol 2003, 18(6):292-298.

30. Hughes AL: The evolution of functionally novel proteins after gene duplication. Proc $R$ Soc B 1994, 256(1346):119-124

31. Lynch $M$, Force $A$ : The probability of duplicate gene preservation by subfunctionalization. Genetics 2000, 154(1):459-473.

32. Lu W, Wainwright G, Webster SG, Rees HH, Turner PC: Clustering of mandibular organ-inhibiting hormone and moult-inhibiting hormone genes in the crab, Cancer pagurus, and implications for regulation of expression. Gene 2000, 253(2):197-207.

33. Chang ES, Bruce MJ, Newcomb RW: Purification and amino acid composition of a peptide with molt-inhibiting activity from the lobster Homarus americanus. Gen Comp Endocrinol 1987, 65:56-64.

34. Gard AL, Lenz PH, Shaw JR, Christie AE: Identification of putative peptide paracrines/hormones in the water flea Daphnia pulex (Crustacea; Branchiopoda; Cladocera) using transcriptomics and immunohistochemistry. Gen Comp Endocrinol 2009, 160(3):271-287.

35. King DS, Meredith J, Wang YJ, Phillips JE: Biological actions of synthetic locust ion transport peptide (ITP). Insect Biochem Mol Biol 1999, 29:11-18,

36. Phillips JE, Meredith J, Audsley N, Richardson N, Macins A, Ring M: Locust ion transport peptide (ITP): A putative hormone controlling water and ionic balance in terrestrial insects. Amer Zool 1998, 38(3):461-470.

37. Eads BD, Andrews J, Colbourne JK: Ecological genomics in Daphnia: stress responses and environmental sex determination. Heredity 2008, 100(2):184-190.

38. Keller R, Kegel G, Reichwein B, Sedlmeier D, Soyez D: Biological effects of neurohormones of the $\mathrm{CHH} / \mathrm{MIH} / \mathrm{GIH}$ peptide family in crustaceans. Recent Developments in Comparative Endocrinology and Neurobiology Nijmegen: ShakerRoubos EW, Wendelaar Bonga SE, Vaudry H, De Loof A 1999, 209-212.

39. Laufer H, Johnson M, Demir N, Twidy K, Chang E, Soyez D, Van Herp F, Bagshaw J: Identification of lobster hyperglycemic hormones ( $\mathrm{CHHs}$ ) with mandibular organ inhibiting activity. SICB Annual Meeting: 2003, Toronto, Canada 2003.

40. Wainwright G, Webster SG, Wilkinson MC, Chung JS, Rees HH: Structure and significance of mandibular organ-inhibiting hormone in the crab, Cancer pagurus - Involvement in multihormonal regulation of growth and reproduction. J Biol Chem 1996, 271(22):12749-12754.

41. Christie AE, Cashman CR, Brennan HR, Ma M, Sousa GL, Li L, Stemmler EA, Dickinson PS: Identification of putative crustacean neuropeptides using in silico analyses of publicly accessible expressed sequence tags. Gen Comp Endocrinol 2008, 156(2):246-264.

42. Marco HG, Gäde G: Biological activity of the predicted red pigmentconcentrating hormone of Daphnia pulex in a crustacean and an insect. Gen Comp Endocrinol 2010, 166(1):104-110.

43. Dai L, Zitnan D, Adams ME: Strategic expression of ion transport peptide gene products in central and peripheral neurons of insects. J Comp Neurol 2007, 500:353-367.

44. Dircksen H, Tesfai LK, Albus C, Nassel DR: Ion transport peptide splice forms in central and peripheral neurons throughout postembryogenesis of Drosophila melanogaster. J Comp Neurol 2008, 509(1):23-41.

45. Cameron SL, Miller KB, D'Haese CA, Whiting MF, Barker SC: Mitochondrial genome data alone are not enough to unambiguously resolve the relationships of Entognatha, Insecta and Crustacea sensu lato (Arthropoda). Cladistics 2004, 20:534-557.

46. Delsuc F, Phillips MJ, Penny D: Comment on "Hexapod origins: monophyletic or paraphyletic?". Science 2003, 301:1482.

47. Ronquist F, Huelsenbeck JP: MrBayes 3: Bayesian phylogenetic inference under mixed models. Bioinformatics 2003, 19:1572-1574.

48. Goldman N, Yang Z: A codon-based model of nucleotide substitution for protein-coding DNA sequences. Mol Biol Evol 1994, 11:725-736. 
49. Muse SV, Gaut BS: A likelihood approach for comparing synonymous and nonsynonymous nucleotide substitution rates, with application to the chloroplast genome. Mol Biol Evol 1994, 11:715-724.

50. Shapiro B, Rambaut A, Drummond AJ: Choosing appropriate substitution models for the phylogenetic analysis of protein-coding sequences. $\mathrm{Mol}$ Biol Evol 2006, 23(1):7-9.

51. Whelan S, Goldman N: A general empirical model of protein evolution derived from multiple protein families using a maximum-likelihood approach. Mol Biol Evol 2001, 18(5):691-699.

52. Abascal F, Zardoya R, Posada D: ProtTest: Selection of best-fit models of protein evolution. Bioinformatics 2005, 21:2104-2105.

53. Guindon S, Gascuel O: A simple, fast and accurate method to estimate large phylogenies by maximum-likelihood. Syst Biol 2003, 52(5):696-704.

54. Kishino H, Hasegawa M: Evaluation of the maximum likelihood estimate of the evolutionary tree topologies from DNA sequence data, and the branching order in hominoidea. J Mol Evol 1989, 29(2):170-179.

55. Maddison WP, Maddison DR: Mesquite: a modular system for evolutionary analysis. 2009http://mesquiteproject.org, Version 2.6

56. Tsutsui N, Ohira T, Kawazoe I, Takahashi A, Wilder MN: Purification of sinus gland peptides having vitellogenesis-inhibiting activity from the whiteleg shrimp Litopenaeus vannamei. Mar Biotechnol (NY) 2007, 9(3):360-369.

doi:10.1186/1471-2148-10-62

Cite this article as: Montagné et al: Molecular evolution of the crustacean hyperglycemic hormone family in ecdysozoans. BMC Evolutionary Biology 2010 10:62.

\section{Submit your next manuscript to BioMed Central and take full advantage of:}

- Convenient online submission

- Thorough peer review

- No space constraints or color figure charges

- Immediate publication on acceptance

- Inclusion in PubMed, CAS, Scopus and Google Scholar

- Research which is freely available for redistribution

Submit your manuscript at www.biomedcentral.com/submit 